Al-Manhaj: Journal of Indonesian Islamic Family Law, 2 (2), 2020: 110-127

ISSN: 2715-003; E-ISSN 2714-5514

DOI: http://dx.doi.org/10.19105/al-manhaj.v111.3735

\title{
Pemenuhan Nafkah Istri dan Anak Oleh Suami Terpidana di Desa Taro'an Kecamatan Tlanakan Kabupaten Pamekasan
}

\author{
Fifi Sriwahyuni \\ (Institut Agama Islam Negeri (IAIN) Madura, email: fifi97@gmail.com)
}

\begin{abstract}
Abstrak:
Di desa Taro'an kondisi nafkah istri dan anak anaknya mendapat perhatian bahkan dari pihak mertua. Faktor itulah yang membuat rumah tangga utuh dan harmonis meskipun suami mendekam di penjara. Berdasarkan konteks diatas, maka permasalahan pokok penelitian ini : Pertama. Bagaimana pemenuhan nafkah istri dan anak oleh suami terpidana di desa Taro'an Kecamatan Tlanakan Kabupaten Pamekasan. Kedua, Bagaimana pandangan Hukum Islam terhadap pemenuhan nafkah istri dan anak oleh suami terpidana di desa Taro'an Kecamatan Tlanakan Kabupaten Pamekasan. Penelitian ini menggunakan pendekatan kualitatif deskriptif. Penelitian ini menunjukkan bahwa; pertama. Pemenuhan nafkah istri dan anak oleh suami terpidana di desa Taro'an kecamatan Tlanakan secara lahiriyah masih bisa terpenuhi. Namun pemenuhan nafkah batin belum tersalurkan kecuali dalam hal interaksi face to face saat si istri melakukan kunjungan ke penjara. Kedua, pandangan hukum Islam terhadap pemenuhan nafkah istri dan anak oleh suami terpidana di desa Taro'an kecamatan Tlanakan kabupaten Pamekasan adalah wajib. (In Taro'an village, the conditions for the living of the wife and children received attention even from the parents-in-law. That factor is what makes the household intact and harmonious even though the husband is in prison. Based on the above context, the main problems of this research are: First. How do the husbands of the convicted husband fulfill their wives and children in Taro'an Village, Tlanakan District, Pamekasan Regency. Second, how is the view of Islamic law on the fulfillment of the husband's wife and children in Taro'an Village, Tlanakan District, Pamekasan Regency. This research uses a descriptive qualitative approach. This research shows that; first. The husband convicted in Taro'an village, Tlanakan
\end{abstract}


subdistrict, physically fulfills the livelihoods of his wife and children. However, the fulfillment of the inner livelihood has not been channeled except in terms of face to face interactions when the wife visits the prison. Second, the view of Islamic law on the fulfillment of the livelihood of the wife and children by the husband of the convicted husband in Taro'an village, Tlanakan sub-district, Pamekasan district is obligatory.)

\section{Kata Kunci:}

Nafkah istri dan anak, suami, penjara.

\section{Pendahuluan}

Semua jenis makhluk hidup memiliki kodrat berpasangpasangan. Dalam kehidupan manusia, sebagai satu-satunya bentuk berpasang-pasangan yang benar. Dengan demikian mudah dimengerti apabila ajaran Islam mendorong pemeluknya yang sudah baligh dan mampu secara ekonomi, untuk segera melangsungkan pernikahan. Oleh karena itu, dengan menikah manusia dapat memelihara statusnya sebagai makhluk yang mulia dalam menyalurkan kebutuhan biologisnya. Selain itu, pernikahan merupakan cara terbaik untuk meneruskan keturunan sendiri. ${ }^{1}$

Allah SWT berfirman:

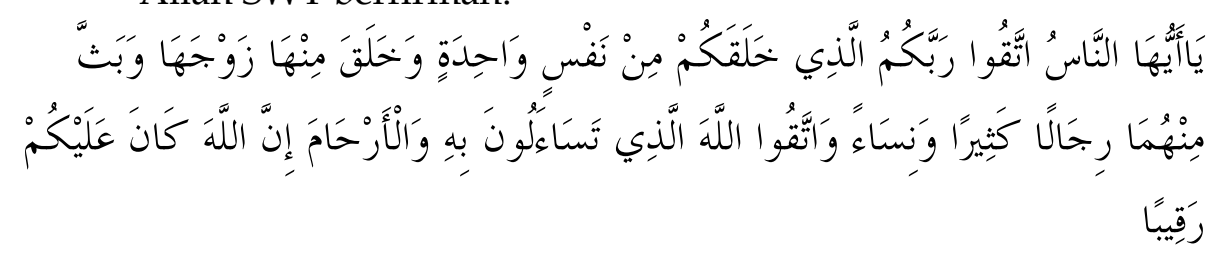

Artinya: Hai sekalian manusia bertakwalah kepada Tuhanmu yang telah menciptakan kamu dari seorang diri, dan menjadikan istri dari padanya, dan dari keduanyaAllah memperkembang-biakkan pria dan wanita yang banyak (QS. al-Nisa' : 1). ${ }^{2}$

Dari ayat di atas sudah jelas bahwasanya Allah telah memerintahkan kepada makhluknya agar bertakwa kepadanya, juga hlm. 170

1 Sudono Sueb, Buku Pintar Agama Islam, (Jatim: Delta Media, 2011),

2 Departemen Agama, Al-Quran Tafsir Perkata Tajwid Kode Angka (Tangerang Selatan: Kalim, 2011), hlm, 77. 
mengingatkan mereka akan kekuasaannya yang telah menciptakan seorang laki-laki dan perempuan untuk menjadikannya sebuah ikatan perkawinan yang nantinya akan melahirkan keturunan dari keduanya.

Agama Islam sangat menganjurkan perkawinan yang dinyatakan dalam al-quran dan hadits. Perkawian merupakan salah satu sunnatullah yang dikehendaki Allah untuk para hambanya. Ini sudah menjadi hukum alam, bahwa pernikahan sebenarnya merupakan salah satu syariat untuk semua makhluk meliputi alam, manusia maupun hewan. ${ }^{3}$

Dengan melakukan perkawinan sesuai dengan syariat islam, Allah menjanjikan akan memberikan kehidupan yang berkecukupan dan menghilangkan berbagai macam kesulitan. Islam menyukai perkawinan dan segala akibat baik yang bertalian dengan perkawinan, baik yang berkaitan dengan masyarakat maupun dengan kemanusiaan. Karena dalam perkawinan itu dapat menentramkan jiwa, menahan emosi, menutup pandangan dari yang dilarang Allah. ${ }^{4}$

Perkawinan harus dimaknai bukan hanya sekedar hubungan kemitraan antara suami istri. Karena ikatan perkawinan berkaitan juga dengan kemitraan dan tanggung jawab kepada Allah SWT. Dalam ikatan perkawinan terdapat perjanjian ganda yaitu perjanjian antara pasangan suami istri dan antara keduanya dengan Allah tujuannya pun harus dicari dalam konteks spiritual.

Adanya suatu ikatan yang sah, akan menimbulkan akibat hukum diantara masing-masing pihak yang bersangkutan. Sehingga dengan terjalinnya hubungan suami istri timbullah hak dan kewajiban diantara keduanya. Seorang suami mempuyai kewajiban-kewajiban yang menjadi hak suami. diantara keduanya saling membutuhkan dan saling melegkapi dengan tercapainya tujuan perkawinan yaitu menciptakan keluarga yang aman dan tenteram dan mempunyai tanggung jawab dari masing-masing pihak yang nantinya akan tercapainya keluarga sakinah, mawaddah dan warahmah.

Pemenuhan kebutuhan biologis merupakan hal penting dalam memelihara keutuhan kehidupan perkawinan, tetapi tentu bukan segala-galanya. Dalam beberapa teori menempatkan aspek

\footnotetext{
3 Sudono Sueb, Buku Pintar Agama Islam, hlm. 172.

4 Syaikh Sulaiman Ahmad Yahya Al-faifi, Fikih Sunnah Sayyid Sabiq, (Jakarta: Pustaka Al-kautsar), hlm. 530
} 
pemenuhan kebutuan biologis sebagai unsur pokok dalam keluarga, kebutuhan biologis bagi suami atau istri, cukup penting untuk dipenuhi, meski bukan hanya untuk memenuhi kebutuhan biologis saja yang menjadi tujuan perkawinan. Pemenuhan kebutuhan biologis adalah kebutuhan bersama, oleh karena itu tidak boleh dipaksakan. ${ }^{5}$

Dengan adanya hubungan biologis sesungguhnya hubungan suami istri tersebut telah mengokohkan bangunan rumah tangga dan menguatkan jalinan cinta serta kasih sayang yang telah mereka bina bersama. Meskipun kebutuhan biologis bukan termasuk tujuan utama, akan tetapi kebutuhan biologis tersebut memegang peranan penting dalam sebuah perkawinan, karena dengan terpenuhnya kebutuhan ini maka tujuan lain dari sebuah perkawinan sudah dapat terpenuhi juga seperti terjadinya proses regenerasi juga terciptanya suasana penuh cinta juga kasih sayang diantara keduanya.

Pada dasarnya rumah tangga itu ditegakkan atas dasar cinta (mawaddah) sehingga cinta ini akan menimbulkan sikap saling mementingkan yang dicintai (suami istri), dan karena sikap saling mementingkan yang lain ini, maka masing-masing suami istri akan memberikan hak yang satu-satunya melebihi kewajibannya dan tidak suka menuntut haknya sendiri. Adapun jika rasa kasih ini sudah mulai kendor, maka rumah tangga masih disangga dengan pondasi yang kedua yaitu berupa kasih sayang (warahmah), disini hak-haknya diperteguh sehingga tidak terabaikan. Karena apabila suatu waktu terjadi cintanya mengendor maka kasih sayang itu dapat mendorong masing-masing suami istri untuk berlemah lembut. ${ }^{6}$

Sebagai suatu organisasi terkecil dalam masyarakat, keluarga harus digerakkan dengan kecukupan dalam aspek ekonomi. Aspek ekonomi penting dipertimbangkan dalam membangun keluarga, sebab kelestarian keluarga juga dipengaruhi oleh aspek ekonomi. Dalam tradisi masyarakat faktor ekonomi bagi masing-masing calon, terutama kaum pria sebagai kepala rumah tangga merupakan kriteria yang tidak dapat diabaikan karena faktor ekonomi disini merupakan penentu kedua setelah faktor komonikasi yang memicu terjadinya

${ }^{5}$ Ulfatmi, Keluarga Sakinah Dalam Perspektif Islam, (Padang:Kementeria Agama, 2011), hlm. 94.

6 Syuqqah Abdul Halim Abu, Kebebasan Wanita, (Jakarta: Gema Insani Press, 1999), hlm. 229. 
perselingkuhan yang akan membuat rumah tangga tidak harmonis dan berantakan.

Membina sebuah rumah tangga memang bukan hanya untuk saling menguasai dan memiliki antara satu pihak dengan pihak yang lain. Karena pernikahan bukan hanya sebagai sarana pemuas nafsu seksual semata. Di dalamnya terdapat banyak tugas dan kewajiban yang besar bagi kedua belah pihak termasuk tanggung jawab ekonomi. ${ }^{7}$

Nafkah merupakan satu hak yang wajib dipenuhi oleh seorang suami terhadap istrinya, nafkah ini bermacam-macam, bisa berupa makanan, tempat tinggal, pelajaran (perhatian), pengobatan, dan juga pakaian meskipun wanita itu kaya.Firman Allah Q.S Al-Baqarah ayat 233:

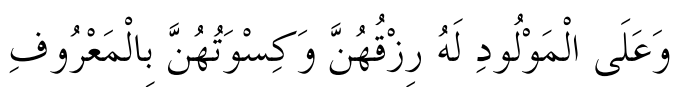

Artinya: Dan kewajiban ayah memberi makan dan pakaian kepada para ibu dengan cara ma'ruf. ${ }^{8}$

Kewajiban memberi nafkah ada di pihak suami, maka suami tidak boleh mengabaikannya. Apabila berlaku bakhil yang semestinya mampu mencukupi nafkah anak dan istrinya, lantaran kebakhilannya ia jarang memberikan belanja kepadanya, maka suami sudah dianggap melalaikan tanggung jawabnya. Dalam memberikan nafkah, suami tidak dibatasi oleh permintaan istrinya. Maksudnya, tidak ada jumlah tertentu yang dapat dikerahkan untuk biaya hidup jumlah itu tergantung pada kemampuan suami.

Dalil-dalil tersebut diatas merupakan dasar kewajiban nafkah secara lahiriyah (materi) yang harus diberikan oleh seorang suami untuk keluarganya (istri dan anak) dengan cara yang ma'ruf sesuai dengan kadar kemampuan yang dimilikinya.

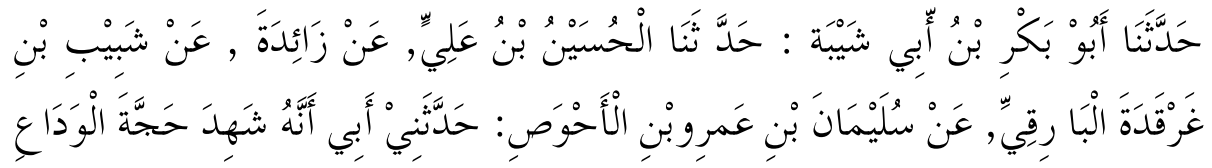

7 Abdul Ghoffar, Fikih Wanita, (Jakarta: Pustaka Al-Kautsar, 2014), hlm. 429.

${ }^{8}$ Departemen Agama, Al-Quran Tafsir Perkata Tajwid Kode Angka, hlm. 37. 


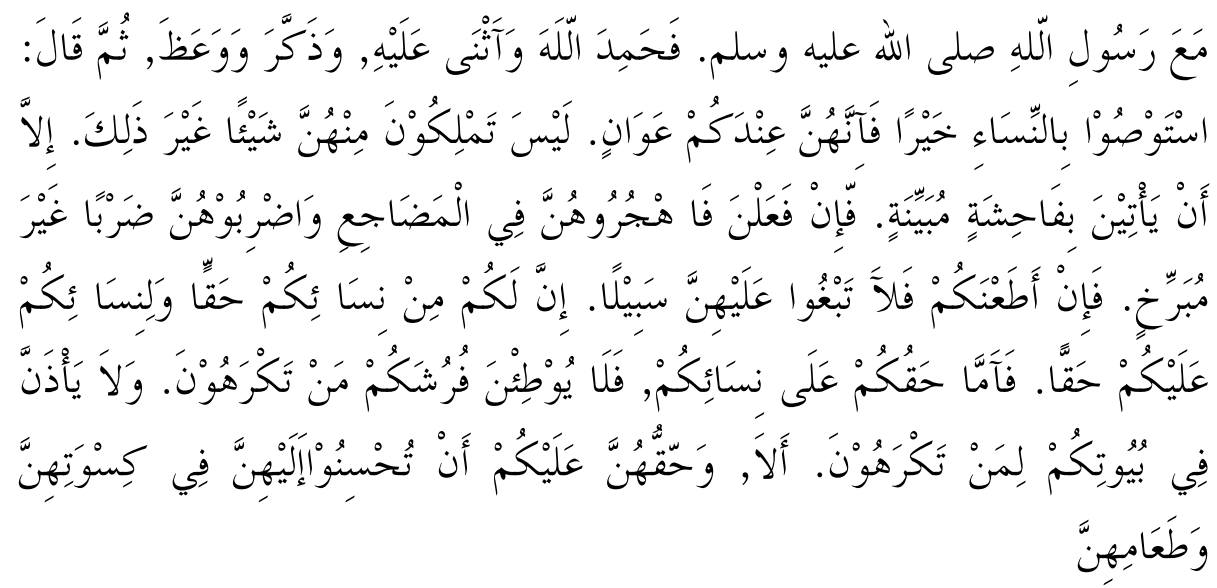

Artinya: Abu Bakar bin Abu Syaibah menyampaikan kepada kami dari AlHusain bin Ali, dari Za'idah, dari Syabib bin Gharqadah Al-Bariqi, dari Sulaiman bin Amr bin Al-Ahwash bahwa ayahnya ikut bersama Rasulullah SAW dalam haji wada'. Setelah bertahmid, memuji Allah, mengingatkan, dan menasihati kami, beliau pun bersabda, "berilah nasihat kebaikan kepada para wanita karena mereka adalah (laksana) tawanan (bagi) kalian, dan kalian tidak memiliki apapun dari mereka selain itu, kecuali jika mereka berbuat keji secara nyata. Apabila mereka berbuat demikian, tinggalkan mereka ditempat tidur (pisah ranjang) dan pukul mereka dengan pukulan yang tidak menyakitkan. Namun jika mereka mematuhi kalian maka janganlah mencari-cari jalan untuk menyakiti mereka. Kalian memiliki hak atas istri dan istri kalian pun memiliki hak atas kalian. Hak kalian sebagai suami atas istri adalah mereka tidak berbicara dan mengizinkan orang yang tidak kalian suka untuk masuk ke rumah. Ketahuilah, hak mereka atas kalian adalah kalian memberikan pakaian dan makanan yang baik untuk mereka. ${ }^{9}$

Hadis di atas menjelaskan bahwa Suami memiliki hak atas istri dan istripun juga memiliki hak atas suaminya. Adapun kewajiban atau hak istri yang harus dijalankan oleh suami ialah memberikan nafkah kepada Istri dalam bentuk kebutuhan yang pokok, di antaranya bijibijian, beras, gandum dan sebagainya yang menjadi makanan pokok di

9 Abu Abdullah Muhammad bin Yazid Al-Qarwini Ibnu Majah, Ensiklopedia Hadis 8 Sunan Ibnu Majah, Hadis Nomor 1851. 
daerah setempat serta memberikan pakaian yang patut dipakai oleh Istri. Di sisi lain, suami wajib melengkapi alat-alat dapur dan alat-alat minum dan juga nafkah yang wajib diberikan oleh suami kepada istri adalah menyediakan pembantu. Dan begitupun sebaliknya jika suami sedang bepergian maka istri tidak boleh memasukkan laki-laki lain ke dalam rumah tanpa seizin dan sepengetahuan suaminya.

Nafkah merupakan hal yang pokok dalam ikatan perkawinan, yang harus dipenuhi oleh seorang suami untuk isterinya. Dengan adanya nikah beberapa kebutuhan bisa terpenuhi. Agama Islam telah mengajarkan bahwa kewajiban suami terhadap istri dalam hak yang bersifat bukan kebendaan salah satunya adalah memenuhi nafkah batin suami istri.

Nafkah batin adalah perbuatan yang dilakukan untuk memenuhi kebutuhan yang harus dipenuhi oleh keluarga baik suami maupun istri yang tidak berbentuk materi seperti kasih sayang, cinta dan hubungan persetubuhan. Memberikan nafkah itu wajib bagi suami sejak akad nikahnya sudah sah dan benar, maka sejak itu seorang suami wajib menanggung nafkah istrinya dan ini berarti berlakulah segala konsekwensinya secara spontan. Dalam hal ini seorang suami itu mempunyai tanggung jawab hak penuh kepada istrinya dengan cara yang baik sesuai dengan hukum syariat islam, maka dari itu telah dijelaskan dalam firman Allah (surah Al-baqarah:228).

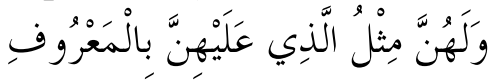

Artinya :"Dan para wanita mempunyai hak yang seimbang dengan beban yang dipikulnya yang harus dibayar oleh lelaki (suami) dengan cara yang ma'ruf."

Maksud dari ayat diatas Istri mempunyai hak yang seimbang dengan kewajibannya, juga Istri memiliki hak untuk diperlakukan secara baik menurut Syari'at dan hak untuk terbebas dari saling menyakiti. Akan tetapi Suami memiliki hak yang lebih atas Istrinya, karena itu Istri wajib patuh kepadanya sebab Suami bertanggung jawab memberikan mas kawin dan nafkah untuk kesejahteraan hidup mereka.

Dalam realita kehidupan terdapat beberapa hal yang tidak dapat dihindari oleh manusia, kehendak manusia tentunya tidak seterusnya selaras dengan apa yang dikehendaki oleh Allah SWT., oleh 
karena itu ada beberapa hal yang dalam hal ini dapat menyebabkan terhalangnya suami untuk memenuhi kewajiban memberi nafkah terhadap keluarga, seperti halnya sakit, cacat, dan suami yang hidupnya dipenjara (narapidana).

Di desa Taro'an Kecamatan Tlanakan Kabupaten Pamekasan terdapat beberapa kasus pidana yang menyebabkan beberapa suami harus menjalani kehidupannya di balik jeruji besi, sehingga konsekuensi yang timbul menyebabkan terbengkalainya kewajiban suami untuk menafkahi keluarga.

Peneliti melakukan penelitian awal di Desa Taro'an Kecamatan Tlanakan Kabupaten Pamekasan dan menemukan tiga suami terpidana, Diantara ketiga pasangan tersebut pemenuhan nafkah lahirnya bermacam-macam, ada yang didapat dari pemberian orang tua suami (mertua), mulai dari kebutuhan yang bersifat primer maupun sekunder, perpindahan tanggung jawab ini berlangsung selama suami masih dalam masa tahanan. Orang tua suami merasa bertanggung jawab atas kehidupan istri dan anak-anaknya dikarenakan anaknya (suami) masih tinggal serumah dengan orang tua dalam artian seluruh kebutuhan biaya hidup menjadi tanggung jawab bersama baik orang tua ataupun suami. Selain itu ada yang istrinya usaha sendiri, orang tua suami tidak ikut bertanggung jawab atas kewajiban anaknya dalam memberikan nafkah terhadap keluarga yang ditinggalkan, walaupun demikian mertua kadang kala memberikan sedikit bantuan untuk meringankan beban dan jerih payah istri dalam menghidupi keluarganya.

Dalam hal ini istri harus bekerja keras karena secara otomatis dia harus menjalankan dua tanggung jawab sekaligus yaitu tanggung jawab lahiriyah sebagai seorang istri, bagaimana menjadi ibu rumah tangga yang bisa mengayomi anak-anaknya, selain itu dia juga harus bisa menjadi kepala rumah tangga yang dapat memimpin dan menafkahi keluarganya selama suami belum bebas dari penjara.

Cara yang terakhir adalah pemenuhan nafkah yang dilakukan oleh suami terpidana, ada yang dengan berdagang yaitu istri membelikan barang-barang dagangan yang kemudian dikirimkan kepada suami untuk diperdagangkan dipenjara. Ada juga yang membuat kerajinan tanganyang hasilnya diperdagangkan di dalam penjara. Cara yang terakhir ini seharusnya dapat ditiru oleh 
narapidana yang masih mempunyai tanggung jawab nafkah terhadap keluarganya, para suami tetap berjuang dan bekerja keras meski dalam keadaan terpidana walaupun secara keseluruhan kebutuhan biaya hidup keluarga yang ditinggalkan tidak secara utuh dapat dipenuhi, dengan ini setidaknya suami tidak lari dari tanggung jawab untuk memenuhi nafkah keluarganya.

Dalam kehidupan keluarga pemenuhan nafkah tidak hanya nafkah lahir saja melainkan nafkah batin pun harus juga dipenuhi oleh suami. Nafkah batin yang diberikan oleh suami terpidana tidak seberat nafkah lahir, karena lembaga permasyarakatan (LAPAS) tidak menyediakan tempat khusus untuk pemenuhan nafkah batin. Biasanya istri mengunjungi suami dua kali dalam seminggu baik untuk memenuhi nafkah batin maupun nafkah lahir. Dalam masalah hasrat ataupun perasaan sulit untuk dijelaskan karena hal ini merupakan urusan pribadi yang sulit disentuh oleh orang lain, yang pada intinya sampai saat ini hubungan jarak jauh yang dilakukan masih tetap harmonis.

Realita di atas sudah berlangsung sekian lama dan sudah menjadi suatu keanekaragaman cara pemenuhan nafkah terhadap keluarga mereka. Namun secara garis besar para suami terpidana masih belum bisa memenuhi secara sempurna dalam kewajibannya terhadap pemberian nafkah, sehingga istri-istri mereka harus banting tulang untuk bisa memenuhi kebutuhan hidup sehari-hari. Keadaan ini menghalanginya untuk memberi nafaqah pada seorang istri untuk memenuhi tanggung jawab sebagai kepala rumah tangga dan hal ini sedikit berlawanan dengan hukum islam, tentang bagaimana kewajiban suami memberi nafkah dan sistem pemenjaraan dalam sanksi pelanggaran pidana. Akan tetapi hal ini tidak dapat dihindari, karena telah menjadi ketetapan negara yang harus dipatuhi oleh seluruh warga negara.

Melihat kenyataan tersebut, penulis tertarik ingin meneliti mengenai "Pemenuhan Nafkah Istri dan Anak oleh Suami Terpidana di Desa Taro'an Kecamatan Tlanakan Kabupaten Pamekasan”. Dengan maksud untuk mengetahui yang dilakukan oleh seorang narapidana untuk menghidupi keluarga dan mengetahui kehidupan keluarga yang ditinggal agar tetap dapat bertahan tanpa kepala keluarga sebagai pencari nafkah dalam keluarga. 
Adapun yang menjadi fokus penelitian berdasarkan latar elakang di atas adalah sebagai berikut: Pertama, bagaimana pemenuhan nafkah istri dan anak oleh suami terpidana di Desa Taro'an Kecamatan Tlanakan Kabupaten Pamekasan? Kedua, bagaimana pandangan Hukum Islam terhadap pemenuhan nafkah istri dan anak oleh suami terpidana di Desa Taro'an Kecamatan Tlanakan Kabupaten Pamekasan?

\section{Metode Penelitian}

Pada penelitian ini peneliti menggunakan pendekatan kualitatif yakni memaparkan data secara deskriptif. Penelitian kualitatif adalah prosedur penelitian yang menghasilkan data deskriptif berupa katakata tetulis atau lisan dari orang-orang dan perilaku yang diamati ${ }^{10}$ Temuan-temuan ini tidak diperoleh dengan metode menghitung atau statistik melainkan dengan cara berbaur secara langsung. Hal ini untuk memahami tentang apa yang dialami oleh subjek penelitian misalnya perilaku, persepsi, motivasi, tindakan, dan lain sebagainya.

Menggunakan pendekatan kualitatif karena hal ini lebih difokuskan terhadap fakta yang terjadi dilapangan dan landasan teori sebagai pemandu agar memperoleh kebenaran yang sesuai dengan mencari dan mengetahui informasi yang benar. Oleh karena itu, penelitian ini menggunakan jenis penelitian studi kasusberkaitan dengan Pemenuhan Nafkah Istri dan Anak oleh Suami Terpidana di Desa Taro'an Kecamatan Tlanakan Kabupaten Pamekasan, yang di dapat melalui pengetahuan peneliti.

Dalam penelitian kualitatif, yang menjadi instrument atau alat penelitian adalah peneliti sendiri.Peneliti menjadi human instrument yang berfungsi menetapkan fokus penelitian, memilih informan sebagai sumber data, melakukan pengumpulan data,membuat kesimpulan dan peneliti bertindak sebagai pengamat non pastisipan di Desa Taro' an Kecamatan Tlanakan Kabupaten Pamekasan.

Lokasi penelitian ini adalah di desa Taro'an kecamatan Tlanakan kabupaten Pamekasan. Lokasi tersebut dianggap layak oleh peneliti untuk diteliti karena peneliti mempunyai keinginan untuk mengetahui Pemenuhan nafkah istri dan anak oleh suami terpidana

10 Lexy J.moleong, Metodologi Penelitian Kualitatif,(Bandung: PT.Remaja Rosdakarya Offset, 2017), hlm.6. 
dan pandangan hukum islam terhadap pemenuhan nafkah istri tersebut. Hal inilah yang kemudian menjadikan peneliti memilih untuk melakukan penelitian dilokasi tersebut

\section{Konsep Perkawinan}

Nikah adalah ikatan yang bertujuan menghalalkan pergaulan bebas dan menghalakan hubungan kelamin antara sorang laki-laki dan seorang perempuanyang sebelumnya tidak halal. Dalam pandangan Islam bukan halalnya hubungan kelamin itu saja yang menjadi tujuan tertinggi, tetapi bertujuan untuk mendapatkan keturunan yang sah dalam rangkaian melanjutkan generasi. ${ }^{11}$

Perkawinan adalah menaati perintah Allah serta sunnah RasulNya, yaitu menciptakan suatu kehidupan rumah tangga yang mendatangkan kemaslahatan, baik bagi pelaku perkawinan itu sendiri, perkawinan tidak hanya bersifat kebutuhan internal yang bersangkutan tetapi juga mempunyai keterkaitan eksternal yang didalamnya melibatkan banyak pihak sebagai satu persatuan yang kokoh. Menurut undang-undang No. 1 Tahun 1974 tentang perkawinan yang dibuat dalam pasal 1 yang berbunyi perkawinan adalah ikatan lahir batin antara seorang laki-laki dan seorang wanita sebagai hubungan suami istri dengan tujuan membentuk keluarga yang bahagia berdasarkan ketuhanan yang Maha Esa.

Di dalam hukum Islam bahwa perkawinan diklasifikasikan menjadi lima (5) bagian diantaranya yaitu: wajib, sunnah, haram, makruh, dan mubah.

Di dalam penetapan hukum perkawinan didasarkan pada pemahaman terhadap sejumlah nash (Al-Qur'an dan Al-Hadis) yang mengisyaratkan tentang tujuan perkawinan diantaranya yaitu:

Kesatu, Untuk memperoleh ketenangan dan ketentraman .

Kedua, Untuk meneruskan keturunan.

Ketiga, Untuk memenuhi hasrat biologis, yakni menyalurkan hanya kepada pasangan perkawinan yang sah.

Keempat Tercapainya kesetaraan relasi atau keseimbangan hubungan antara suami dan istri.

${ }^{11}$ Beni Ahmad Saebani, Fiqih Munakahat, (Bandung: CV. Pustaka Setia, 2001), hlm.15. 
Kelima Untuk menjaga kehormatan, kehormatan yang dimaksud adalah kehormatan diri sendiri, anak dan keluarga secara tersirat.

Keenam, Untuk mengabdi dan beribadah kepada Allah .

Ada beberapa prinsip perkawinan yang disandarkan pada ayatayat Al-Qur'an diantaranya yaitu: prinsip kebebasan memilih jodoh; prinsip mawaddah warahmah; prinsip saling melengkapi dan melindungi; prinsip mu'asyarah bi al-ma'ruf;

\section{Komsep Nafkah}

Nafkah adalah memenuhi segala kebutuhan istri yang meliputi makan, tempat tinggal, pelayanan dan obat, meskipun istri adalah orang yang sangat berkecukupan/ kaya.12 Sedangkan النفة dalam bahasa berasal dari kata انفق , yang artinya berarti mengeluarkan dan habis. Menurut fiqih, النفقةialah segala yang dihajatkan manusia, baik berupa makanan, minuman, pakaian maupun tempat tinggal, kebutuhan-kebutuhan ini disebut نققة atau nafkah karena akhirnya akan habis dan sirna bila digunakan. $2^{13}$ Dari beberapa definisi tersebut dapat disimpulkan bahwa nafkah adalah pemberian suami kepada istri yang berupa materi atau non materi yang masih menjadi tanggung jawab suami terhadap istri.

Adapun dasar hukum nafkah adalah QS. At-Thalaq: 6 :

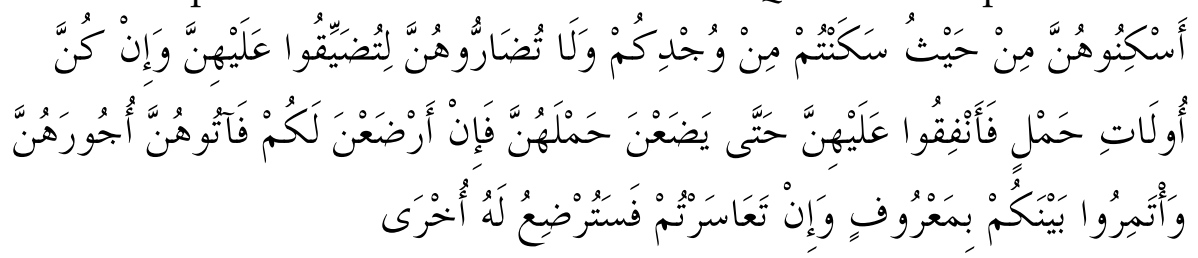

Artinya: Tempatkanlah mereka (para istri) dimana kamu bertempat tinggal menurut kemampuanmu dan janganlah kamu menyusahkan mereka untuk menyempitkan (hati) mereka. Dan jika mereka (istri-istri yang sudah ditalak) itu sedang hamil, maka berianlah kepada mereka nafkahnya hingga mereka bersalin, kemudian jika mereka menyusukan

12 Mudjab Mahalli, Menikahlah Engkau Menjadi kaya, (Yogyakarta: Mitra Pustaka, 2001), hlm. 234.

${ }^{13}$ Anshory Umar Sitanggal, Fiqih Syafi'I Sistimatis, (Semarang: CV Asy Syifa, 1987), hlm. 418. 
(anak-anak) mu untukmu maka berikanlah kepada mereka upahnya, dan musyawarahkanlah diantara kamu (segala sesuatu) dengan baik; dan jika kamu menemui kesulitan maka perempuan lain boleh menyusukan (anak itu) untuknya. (QS. At-Thalaq: 6).

Adapun bentuk-bentuk nafkah menurut siapa yang wajib mengeluarkannya dan siapa yang menerimanya terbagi kepada lima orang diantaranya: Nafkah Istri; Nafkah wanita yang ditalak ba'in sejak masa Iddahnya jika hamil; Nafkah orang tua, dan orang yang wajib memberinya nafkah adalah anaknya;14 Nafkah anak; Nafkah budak, orang yang wajib memberikan nafkah adalah majikannya.

\section{Gambaran Umum Desa Taro'an}

Pada bab ini peneliti akan menggambarkan mengenai lokasi penelitian. Penelitian ini dilakukan di Desa Taro'an Kecamatan Tlanakan Kabupaten Pamekasan. Desa Taro'an terbagi menjadi 3 dusun yakni; Ro' koro', Lompenay, dan Pangjajar. Semua penduduknya beragama Islam. Adapun luas wilayahnya $241 \mathrm{~km}$ atau 24.090. dan jumlah penduduk keseluruhan berkisar 2.298 jiwa yaitu dengan jumlah penduduk lebih banyak perempuan yakni 1.168 jiwa sedangkan laki-laki 1.130 jiwa dari jumlah penduduknya ${ }^{15}$ (Sumber). berikut:

Adapun Batas-batas wilayah Desa Taro'an adalah sebagai

Sebelah Utara : : Desa Samiran

Sebelah Selatan : Desa Larangan Slampar

Sebelah Timur : : Desa Teja Barat

Sebelah Barat : : Desa Toket

Menurut informan bapak Sulaiman seorang seketaris Desa Taro'an, beliau menjelaskan bahwa batas-batas Taro'an adalah sebelah utara Desa Samiran, sebelah selatan Desa Larangan Slampar, sebelah timur Desa Teja Barat, dan sebelah baratnya Desa Toket. ${ }^{16}$

14 Shomad, Hukum Islam Penormaan Prinsip Syari'ah dalam Hukum Indonesia, hlm.230.

15 Tim, Topograrafi desa tahun 2018, tt, h. 10, Sulaiman, Seketaris Desa Taro'an Kecamatan Tlanakan Kabupaten Pamekasan, wawancara langsung di kediaman beliau di Dusun Pangjajar, ( 16 Maret 2018, Jam: 16.00 WIB).

16 Sulaiman, Seketaris Desa Taro'an Kecamatan Tlanakan Kabupaten Pamekasan, wawancara langsung di kediaman beliau di Dusun Pangjajar, ( 16 Maret 2018, Jam: 16.00 WIB). 
Bidang ekonomi merupakan salah satu bidang yang amat penting dalam proses pembangunan potensi ekonomi yang dimiliki oleh masing-masing individu yang cukup berpengaruh pada perekonomian itu sendiri, sesuai dengan kondisi geografinya. Sebagian besar masyarakat Desa Taro'an Kecamatan Tlanakan Kabupaten Pamekasan bermata pencaharian sebagai petani, pedagang, ojek, sopir, TKW, dan pegawai. Dilihat dari penghasilannya kebanyakan dari mereka adalah masyarakat dari ekonomi menengah keatas, tapi tak dipungkiri juga kalau masih ada yang taraf ekonominya yang menengah ke bawah.

Mata Pencarian Penduduk Desa Taro'an

\begin{tabular}{|l|l|l|}
\hline No. & \multicolumn{1}{|c|}{ Mata Pencaharian Pokok } & Jumlah \\
\hline 1. & Petani & 250 orang \\
\hline 2. & Pedagang & 120 orang \\
\hline 3. & Ojek & 10 orang \\
\hline 4. & Sopir angkutan umum & 22 orang \\
\hline 5. & TKI & 20 orang \\
\hline 6. & Pegawai & 25 orang \\
\hline & Jumlah & 447 orang \\
\hline
\end{tabular}

Dari data mata pencaharian masyarakat Taro'an sebagaimana menurut pengamatan penulis taraf ekonominya diperkirakan $60 \%$ dari $100 \%$ rata-rata bekerja sebagai petani petani dan $40 \%$ sebagai pedagang, ojek, sopir angkutan umum, TKI dan pegawai. Jadi masyarakat desa taro'an lebih didominasi oleh petani.

Jenis Rumah Penduduk Taro'an 2018

\begin{tabular}{|l|l|l|}
\hline No. & Jenis Rumah & Jumlah \\
\hline 1. & Rumah Permanen & 250 \\
\hline 2. & Rumah Semi Permanen & 50 \\
\hline & Jumlah & 300 \\
\hline
\end{tabular}

Taraf hidup masyarakat khususnya Desa Taro'an sekarang lebih meningkat dari sebelumnya semenjak sebagian mereka bekerja sebagai tenaga kerja TKI sehingga mereka sudah mampu memperbaiki bahkan membangun rumah secara permanen (berbahan semen dan cor). 
Jumlah Penduduk Taro'an Berdasarkan Jenis Kelamin

\begin{tabular}{|r|r|c|}
\hline No. & Jenis Kelamin & Jumlah (orang) \\
\hline 1. & Laki-laki & 1.130 \\
\hline 2. & Perempuan & 1.168 \\
\hline & Jumlah & 2.298 \\
\hline
\end{tabular}

Dari jumlah penduduk sebanyak 2.298 orang atau jiwa, menurut monografi Desa Taro'an bahwa pada umumnya Desa Taro'an sama dengan Desa yang lainnya yaitu antara jumlah penduduk lakilaki dan penduduk perempuan lebih banyak perempuannya yakni, perempuan 1.168 orang dan laki-laki 1.130 orang.

Sarana dan Prasarana Pemerintahan dan Pelayanan UmumTahun 2018

\begin{tabular}{|c|l|c|}
\hline No. & \multicolumn{1}{|c|}{ Jenis Sarana } & Jumlah \\
\hline 1. & Kantor Kecamatan & 1 \\
\hline 2. & Koramil & 1 \\
\hline 3. & KUA & 1 \\
\hline 4. & POLSEK & 1 \\
\hline 5. & Balai Desa & 1 \\
\hline 6. & Puskesmas & 1 \\
\hline & Jumlah & 6 \\
\hline
\end{tabular}

Dilihat dari jumlah sarana dan prasarana serta pelayanan umum di Desa Taro'an ternyata kurang memadai dalam pelayanan kesehatan masyarakat berupa polindes.

Sarana Ibadah Tahun 2018

\begin{tabular}{|l|c|c|}
\hline No. & Tempat Ibadah & Jumlah \\
\hline 1. & Masjid & 12 \\
\hline 2. & Musholla & 20 \\
\hline & Jumlah & 22 \\
\hline
\end{tabular}

Hasil wawancara dengan informan seketaris kepala Desa Taro' an sudah tergolong lengkap sarana yang telah dimiliki, mulai dari sarana ibadah seperti ada 12 masjid dan ada 20 musholla.

Menurut topografi desa, jarak balai Desa Taro' an menuju pusat pemerintahan kecamatan hanya berjarak $15 \mathrm{~km}$ atau dapat ditempuh kurang lebih 20 menit dan untuk menuju ibu kota Kabupaten 
Pamekasan yang berjarak $5 \mathrm{~km}$ hanya dapat ditempuh dengan 5 menit dengan memakai sepeda motor. Sedangkan jarak Ibu Kota Provinsi 250 $\mathrm{km}$.

Nama Penduduk Taro'an Suami Terpidana

\begin{tabular}{|c|l|l|}
\hline No. & \multicolumn{1}{|c|}{ Suami } & \multicolumn{1}{c|}{ Istri } \\
\hline 1. & Tori & Yanti \\
\hline 2. & Kirman & Sulalah \\
\hline 3. & Mustahep & Hoy \\
\hline 4. & Amin & Warda \\
\hline 5. & Sakur Jumlah & Putihah \\
\hline & \multicolumn{1}{|c|}{5} \\
\hline
\end{tabular}

Dilihat dari daftar nama-nama suami terpidana, maka diantara jenis kejahatan yang dilakukan oleh para penghuni LAPAS sebelum keluar dari tahanan antara lain: pencurian, penyalah gunaan obat-obatan (mengkonsumsi sabu-sabu ) dan pelanggaran lalu lintas yang mengakibatkan kecelakaan.

\section{Temuan Penelitian}

Berdasarkan data yang diperoleh dari hasil wawancara, observasi dan dokumentasi tersebut maka dapat ditemukan hasil temuan penelitian sebagai berikut:

Pelaksanaan Pemenuhan Nafkah Istri dan Anak oleh Suami

Terpidana di Desa Taro'an Kecamatan Tlanakan Kabupaten Pamekasan

Pertama, Pemenuhan nafkah istri dan anak-anaknya masih bisa terpenuhi.

Kedua, Pemenuhan nafkah istri dan anak-anaknya di dapat dari hasil berjualan Suami di area tahanan

Ketiga, Pemenuhan nafkah yang diberikan suami masih belum memenuhi kebutuhan sehari-hari istri, sehingga istri ikut membantu dengan cara usaha sendiri

Keempat, Pemenuhan nafkah istri dan anak-anaknya ditanggung oleh mertua

Kelima, Jumlah nafkah yang diberikan kepada istri berkisar Rp. $200.000,00$ dan Rp. $600.000,00$ per bulan 
Dalam hal ini yang di peroleh oleh peneliti dalam penelitian ini adalah dari bentuk pemenuhan nafkah lahiriyah rata-rata masih terpenuhi meski ada yang kadang-kadang untuk memberikan nafkahnya tersebut. Mengenai nafkah batin masih belum tersalurkan layaknya suami istri, namun nafkah batin yang lain seperti halnya kasih sayang dan maberes kerrong dalam artian melepas rindu masih tersalurkan.

\section{Penutup}

Dari hasil penelitian dapat disimpulkan sebagai berikut:

Pertama, Pemenuhan nafkah istri dan anak oleh suami terpidana di desa Taro'an kecamatan Tlanakan secara lahiriyah masih bisa terpenuhi meskipun suami berada di dalam tahanan dengan cara si istri berjualan di area tahanan, bantuan mertua. Namun pemenuhan nafkah batin belum tersalurkan kecuali dalam hal interaksi face to face saat si istri melakukan kunjungan ke penjara.

Kedua, pandangan hukum Islam terhadap pemenuhan nafkah istri dan anak oleh suami terpidana di desa Taro'an kecamatan Tlanakan Kabupaten Pamekasan adalah wajib.

\section{Daftar Pustaka}

Abidin, Slamet. Fiqih Munakahat 1. Bandung: CV. Pustaka Setia. 1999. Ahmad, Saebani, Beni. Fiqih Munakahat, Bandung: CV. Pustaka Setia.2001.

Al-faifi, Syaikh Sulaiman Ahmad Yahya. Fikih Sunnah Sayyid Sabiq, Jakarta: Pustaka Al-kautsar. 2013.

Buna'i. Penelitian kualitatif. Malang: Perpustakaan STAIN Pamekasan Press. 2008.

Bungin, Burhan. Metodologi Penelitian Kualitatif, Jakarta: PT. Raja Grafindo Persada. 2011.

Dedy Sulistiyanto, Kewajiban Suami Narapidana Terhadap Nafkah Keluarga Study Kasus di Lembaga Permasyarakatan Kelas IIA Beteng Ambarawa, Skripsi Sekolah Tinggi Agama Islam Negeri STAIN Salatiga. 2014.

Departemen Agama, Al-Quran Tafsir Perkata Tajwid Kode Angka, Tangerang Selatan: Kalim, 2011. 
El-Jazairi, Abu Bakar Jabir, Pola Hidup Muslim, Bandung: PT Remaja Rosdakarya, 1991.

Ghoffar, M. Abdul. Fikih Wanita, Jakarta: Pustaka Al-Kautsar. 2014.

Gunawan, Imam. Metode penelitian kualitatif: Teori dan Praktik. Jakarta : Bumi Aksara. 2014.

Halim Abu Syuqqah, Abdul. Kebebasan Wanita, Jakarta: Gema Insani Press. 1998.

Darul Qalam Kuwait. 2000.

Imam Taqiyuddin Abu Bakar Al-Husaini, Kifaayatul Akhyar,Surabaya: PT. Bina Ilmu Offset. 1997.

J. Moleong, Lexy. Metodologi Penelitian Kualitatif. Bandung: PT.Remaja Rosdakarya. 2017.

Mahalli, Mudjab. Menikahlah Engkau Menjadi kaya. Yogyakarta: Mitra Pustaka. 2001.

Mahmud, Al-jauhari Muhammad. Membangun Keluarga Qur'ani, Jakarta: Sinar Grafika Offset. 2000.

Moh.Ramulyo Idris. Hukum Perkawinan Islam, Jakarta: PT. Bumi Aksara. 1999.

Moh. Kasiram. Metodologi Penelitian. Malang: UIN-Maliki Press. 2010. 